Cañas, María.

Agitadora y activadora cultural.

\title{
Investiga, activa y juega, que algo queda.
}

\section{Research, active and play, that something is.}

\author{
TIPO DE TRABAJO: \\ Comunicación invitada. \\ PALABRAS CLAVE: \\ Juego, artivismo, creación colaborativa, risastencia, videoguerrilla.
}

KEY WORDS:

Game, artivism, collaborative creation, risastencia, videoguerrilla.

RESUMEN.

Apuesta en torno al ámbito del vivir y del investigar que se centra en la experimentación artística a través de la "risastencia" (el humor de todos los colores y sabores), el juego, el Do It yourself (DIY), la agitación y las prácticas colaborativas de las multitudes conectadas, como estrategias de insurgencia o, si no, al menos, de resistencia y supervivencia popular. Desafío de defender la carcajada que organiza la rabia... o no, ¿por qué, y si esa rabia al final sólo queda datificada en los muros del ciberespacio?

Defendamos a ultranza la no privatización y la liberalización de nuestra memoria histórica e imaginarios. Seamos activistas comprometidos con la cultura libre y con la idea de cultura como construcción colectiva, como contrahistoria, para practicar una cultura de oposición. ¡Vida eterna al dominio público! Apostemos por unas vidas dignas de ser vividas a lo María Zambrano, por el archivo orgánico de internet y el "detritus" audiovisual que nos rodea como herramientas de desarrollo cultural, y por la necesidad de educar e investigar en el hackeo y reciclaje de nuestros imaginarios, para así transformarnos en seres más libres, críticos y creativos. Seamos en las calles y con el Internet de las cosas o como la denomina O’Reilly, la web encontrando el mundo. Nos corresponde enseñar a personas conscientes y sensibles con lo que ocurre, adaptables a los cambios convulsos y que puedan responder de forma creativa, ecológica y ética a los problemas de nuestro tiempo.

\section{ABSTRACT.}

It bets on the field of living and research that focuses on artistic experimentation through "risastencia" (the humor of all colors and flavors), the game, the Do It yourself (DIY), the agitation and collaborative practices of connected multitudes, as strategies of insurgency or, if not, at least, resistance and popular survival. Challenge to defend the laughter that organizes the rage ... or not, why, and if that rage in the end only remains "datatyped" in the walls of cyberspace?

Let us defend at all costs the non-privatization and liberalization of our historical and imaginary memory. Let us be activists committed to free culture and to the idea of culture as the collective construction, as counter-history, to practice a culture of opposition. Eternal life for the public domain! Let's bet for a life worthy of being lived, by María Zambrano, for the organic file of the internet and the audiovisual "detritus" that surrounds us as tools of cultural development, and for the need to educate and investigate in the hacking and recycling of our imaginaries, to transform us into more free, critical and creative beings. Let's be on the streets and with the Internet of things or as O'Reilly calls it, the web finding the world. It is up to us to teach people who are aware and sensitive to what is happening, adaptable to convulsive changes and who respond creatively, ecologically and ethically to the problems of our time. 


\section{CONTENIDO.}

En la situación de convulsos cambios que estamos viviendo, sospechar de las imágenes es esencial para reactivar nuestro presente. Bienvenidos al frente de la "risastencia". Cuando tanta rabia acumulada nos haría explotar, pero decidimos mejor practicar la carcajada para organizar dicha rabia... o no, ¿̇por qué, y si esa rabia al final sólo queda datificada en los muros del ciberespacio?

¿Y qué es la "risastencia"? Es el humor de todos los colores y sabores como una forma de resistencia popular. Que nuestra bandera sea el humor tocapelotas, políticamente incorrecto, gamberro, fuera de protocolos y que en muchas ocasiones se transforma en una afrenta despiadada a las normas sociales impuestas.

Apostemos en torno al ámbito del vivir y del investigar con la experimentación artística a través de la "risastencia", el juego, el autodidactismo, la agitación y las prácticas colaborativas de las multitudes conectadas, como estrategias de insurgencia o, si no, al menos, de supervivencia.

Seamos una resistencia al maniqueísmo, a la espectacularidad gratuita y demás paparruchas engendradas por la industria del entretenimiento digital para que consumamos y nos consumamos. Generemos ocio amoroso y a la vez terrorífico, que nos haga rugir, porque la revolución no será televisada y se produce en callejones sin salida.

Creamos en los encuentros inspiradores y activadores gracias al apropiacionismo, la "videomaquia", la multitudinaria creación de imágenes amateurs populares, las pedagogías transgresoras, el archivo como patrimonio y dispositivo de creación cultural y la vídeoremezcla política de los ciudadanos conectados. En un liberarse de la rigidez de la academia y su meritocracia, para cabalgar independientes por tierra de nadie al estilo de Alan Moore (2014), Enric Durán, Kenneth Goldsmith (2011), José Mujica, Agnès Varda, Hito Steyerl (2014), Harun Farocki (2013), Werner Herzog (2010), el colectivo Chto Delat, el colectivo Subtramas, Reclaim the Streets, Cine $\sin$ Autor, Flo6x8, Nuria Güell, Santi Cirugeda... En un juego en el que reír y maquinar a medio camino entre el activismo, el show audiovisual, la agitación cultural y la acción patafísica performancera. En saquear iconos, generar relatos "glocales" a contracorriente y la videoguerrilla que subvierte y revive el archivo on-line infinito y el excedente de imágenes del gran teatro del mundo, nos harán sentirnos creativos y salvajes a ratos.

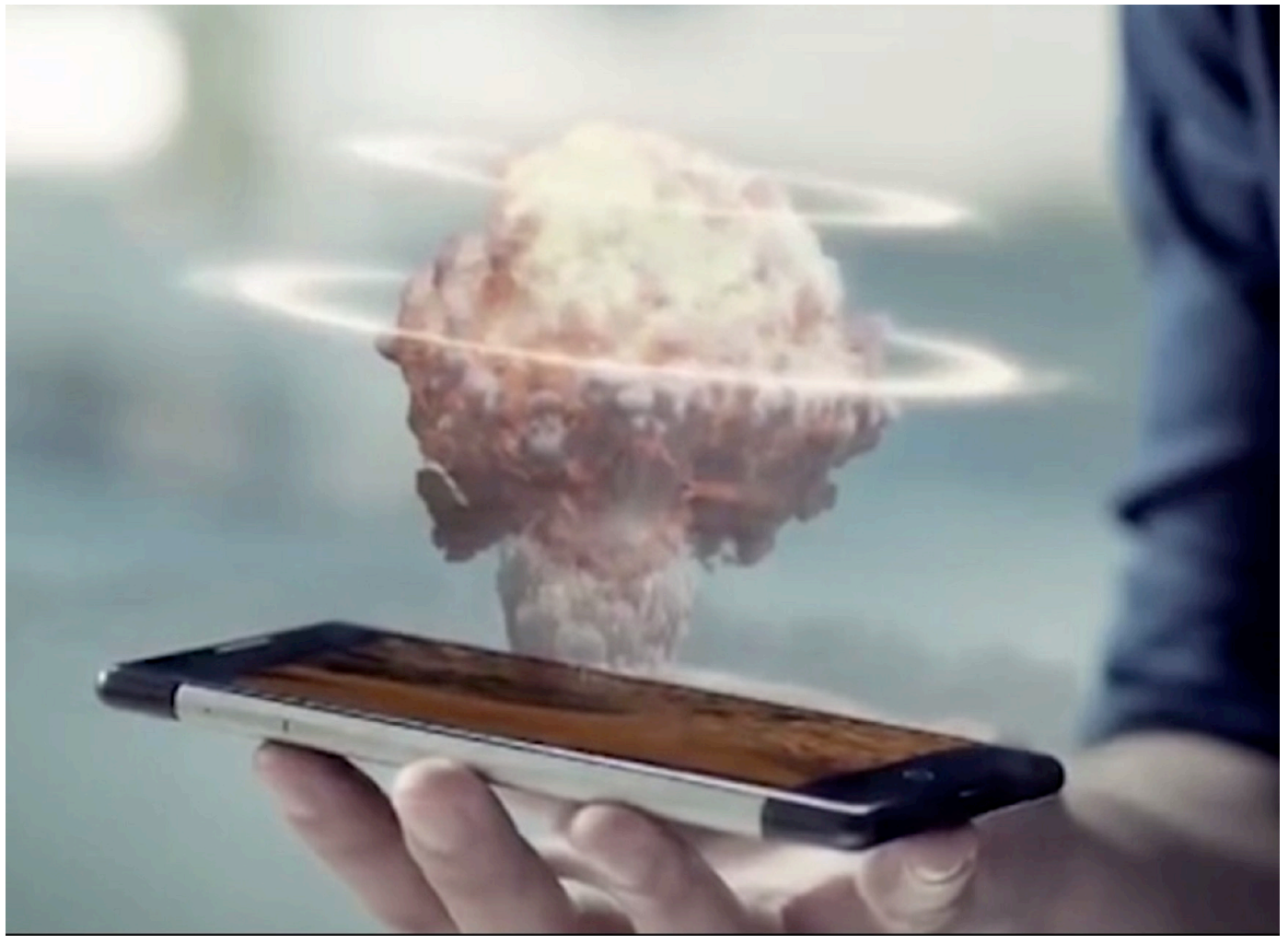

llustración 1. María Cañas. 2015, Frame de La mano que trina. 
Defendamos a ultranza la no privatización y la liberalización de nuestra memoria histórica e imaginarios. Seamos activistas comprometidos con la cultura libre y con la idea de cultura como construcción colectiva, como contrahistoria, para practicar una cultura de oposición. ¡Vida eterna al dominio público! Apostemos por unas vidas dignas de ser vividas a lo María Zambrano (2004), por el archivo orgánico de internet y el "detritus" audiovisual que nos rodea como herramientas de desarrollo cultural, y por la necesidad de educar e investigar en el hackeo y reciclaje de nuestros imaginarios. Seamos en las calles y con el Internet de las cosas o como la denomina O'Reilly, la web encontrando el mundo. Un estado utópico de cosas en que la inteligencia colectiva residiría solamente en las aportaciones y usos de los cibernautas. La inteligencia colectiva aumentaría la consciencia de nuestro entorno y nuestras potenciales opciones de interacción en el mismo. Por soñar que no quede... Nos corresponde enseñar a personas conscientes y sensibles con lo que ocurre, adaptables a los cambios convulsos y que puedan responder de forma creativa, ecológica y ética a los nuevos problemas.

Soñemos que es el momento de filmar lo que nadie filma y donde nadie filma y de hacer cine sin cámaras. Reivindiquemos las narrativas audiovisuales liberadas de las concepciones "bunkerizantes" de la historia y de los géneros: avanzar por tierra de nadie, entre el cine experimental y el videoarte, el documental y el ensayo, la vida y la muerte... Practiquemos la video-remezcla política que se introduce en los tópicos y símbolos para dinamitarlos, que reta al mensaje dominante y a los mitos socioculturales instaurados por los medios de comunicación de masas, transformando los discursos oficiales en versiones low-cost de cultura crítica.

Apasionémonos por agitar las imágenes, para así transformarnos en seres más libres e imaginativos. Que el fuego camine con todos. Y como advertía Simón del Desierto: "No nos dejemos arder en el fuego de una contemplación vana".

¿La realidad supera a la ficción?, ¿la ficción supera a la realidad? Quién sabe... Extraer una enseñanza de lo vivido y visionado, adaptarlo a nuestros fines e inquietudes, estar en este mundo sin ser de este mundo y ser proteicos y felices, eso es lo esencial: no conviene olvidarlo.

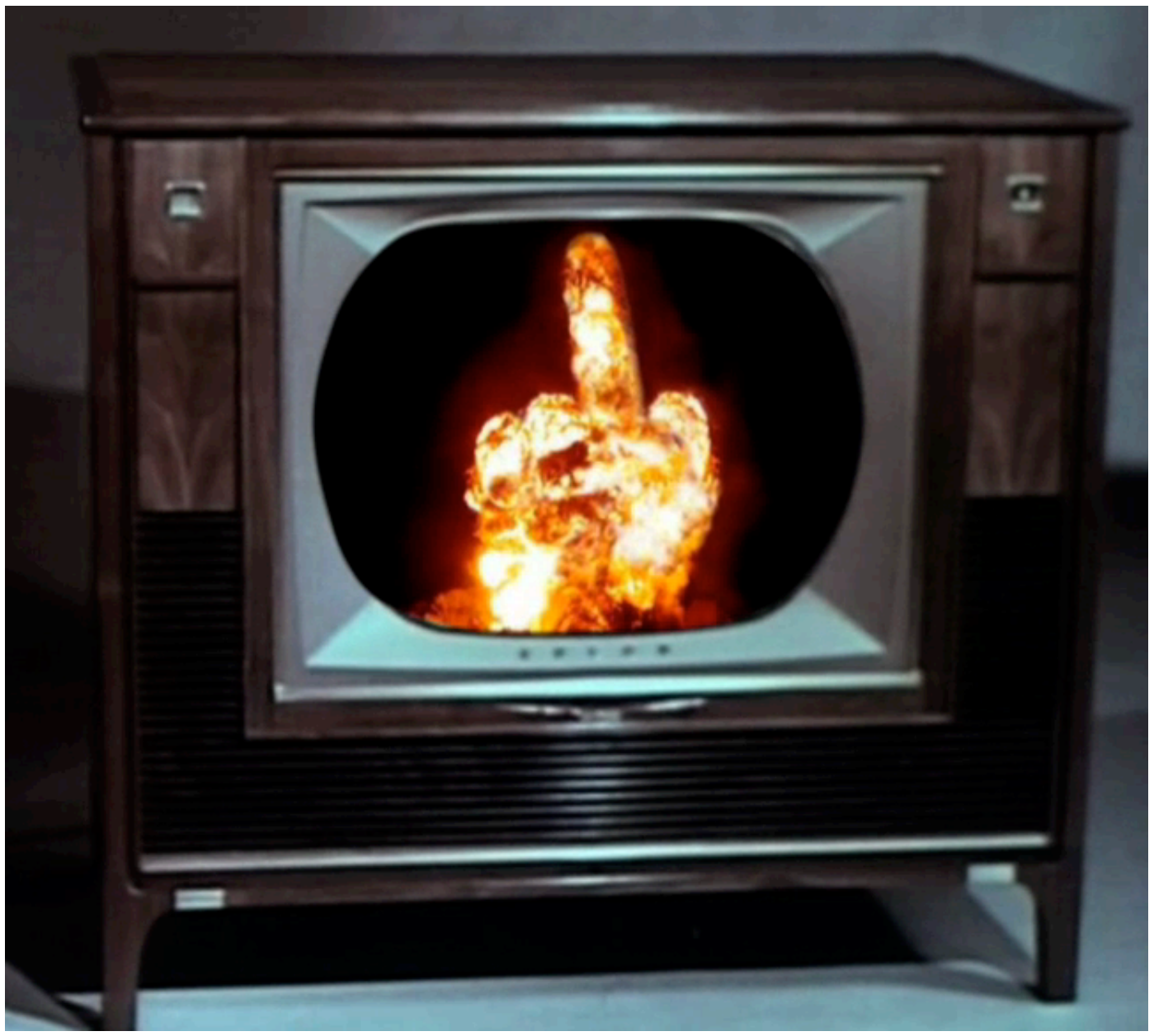

llustración 2. María Cañas. 2012, Frame de Fuera de Serie. 
III CONGRESO INTERNACIONAL DE INVESTIGACIÓN EN ARTES VISUALES :: ANIAV 2017 :: GLOCAL [codificar, mediar, transformar, vivir] http://dx.doi.org/10.4995/ANIAV.2017.6897

\section{FUENTES REFERENCIALES.}

Farocki, H. 2013. Desconfiar de las imágenes. Buenos Aires: Caja Negra

Goldsmith, K. 2011. Escritura no-creativa. Gestionando el lenguaje en la era digital. Buenos Aires: Caja Negra

Herzog, W. 2010. Conquista de lo inútil. Barcelona: Blakkie Books

Moore, A. 2014. Ángeles fósiles. Madrid: Felgera Ediciones

Styerl, H. 2014. Los condenados de la pantalla. Buenos Aires: Caja Negra

Zambrano, M. 2004. Persona y democracia. Madrid: Siruela

Chto Delat: https://chtodelat.org/

Cine sin Autor: https://www.cinesinautor.es/

Flo6x8: http://flo6x8.com/

Reclaim the Streets: http://rts.gn.apc.org/

Santi Cirugeda: http://www.recetasurbanas.net/index1.php

Subtramas: http://subtramas.museoreinasofia.es/es/subtramas 